\title{
Heat Flux Pipe in Large-scale Fire Tests
}

\author{
PETER K. WU \\ FM Global \\ 1151 Boston-Providence Turnpike \\ Norwood, Massachusetts USA
}

\begin{abstract}
This paper presents the results from a series of commodity classification tests conducted with a unique flame heat flux instrument, i.e., Heat Flux Pipe. In the early 1990's, FM Global established the ranking of combustible products with a commodity classification test using benchmark commodities. The methodology used heat release rate calorimetry to determine the hazard level of a commodity. It is well known that flame heat flux is closely linked to flame spread and heat release rates associated with various commodities. In the present test series, the initial sprinklered tests were conducted with Class II and Standard Plastic commodities and a distinct difference in maximum flame heat flux was measured, i.e., $114 \mathrm{~kW} / \mathrm{m}^{2}$ and $192 \mathrm{~kW} / \mathrm{m}^{2}$ respectively. Subsequent freeburn commodity classification tests with Class II, wood pallet and Standard Plastic showed large measured maximum flame heat fluxes, $140 \mathrm{~kW} / \mathrm{m}^{2}, 190 \mathrm{~kW} / \mathrm{m}^{2}$ and $440 \mathrm{~kW} / \mathrm{m}^{2}$ respectively. This difference in flame heat flux between commodities can be exploited to better quantify the commodity hazards and hence the corresponding protection requirements. Also, the Heat Flux Pipe has been shown to be a robust instrument in large fires, up to $30 \mathrm{MW}$, and withstanding flame heat flux level of up to $440 \mathrm{~kW} / \mathrm{m}^{2}$. The Heat Flux Pipe can clearly be used in other fire scenario where flame heat flux measurements are desirable.
\end{abstract}

KEYWORDS: flame, flame spread, flame heat flux, commodity classification

\section{INTRODUCTION}

Fire hazards associated with warehouse commodities are a serious problem. A warehouse typically contains large quantities of commodities that are stored to great heights in racks designed for easy access. Such a storage arrangements provide large fuel surface areas accessible to flames. In early 1990's, Chicarello and Troup [1] developed a standardized fire test procedure (i.e., Commodity Classification Test) to assess the relative hazards of warehouse commodities and established a commodity classification standard [2] based on correlation of heat release rate data. Commodity classification tests were conducted under the Fire Products Collector [3] (Fig. 1) at the FM Global Research Campus with eight pallet loads of commodities in a 2x2x2 arrangement (Figs. 1-3). A specially designed water application system is used to deliver a known rate of water directly onto the burning fuel array. The water applicators were activated automatically by the computer based on Yu's model [4], using real time convective heat release rate and a hypothetical sprinkler protection system.

Chicarello and Troup conducted twenty-one tests with seven commodities. Each commodity was tested using three different water application densities. The commodities were grouped into five classes: Class I, Class II, Class III, Class IV or Standard Plastic. 


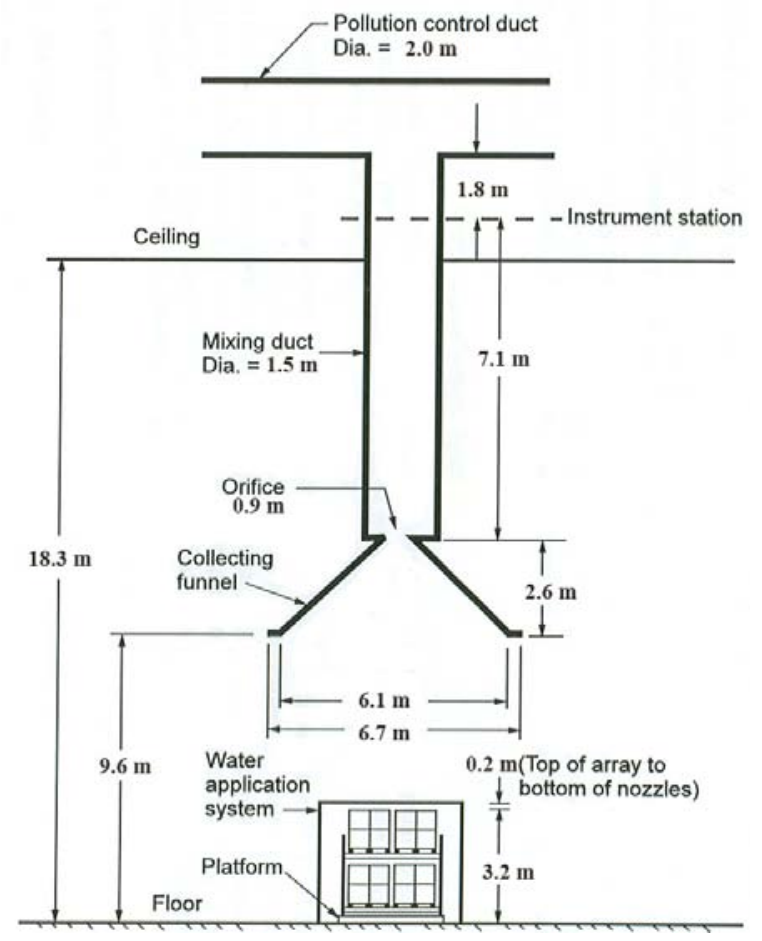

Fig. 1. The fire products collector.

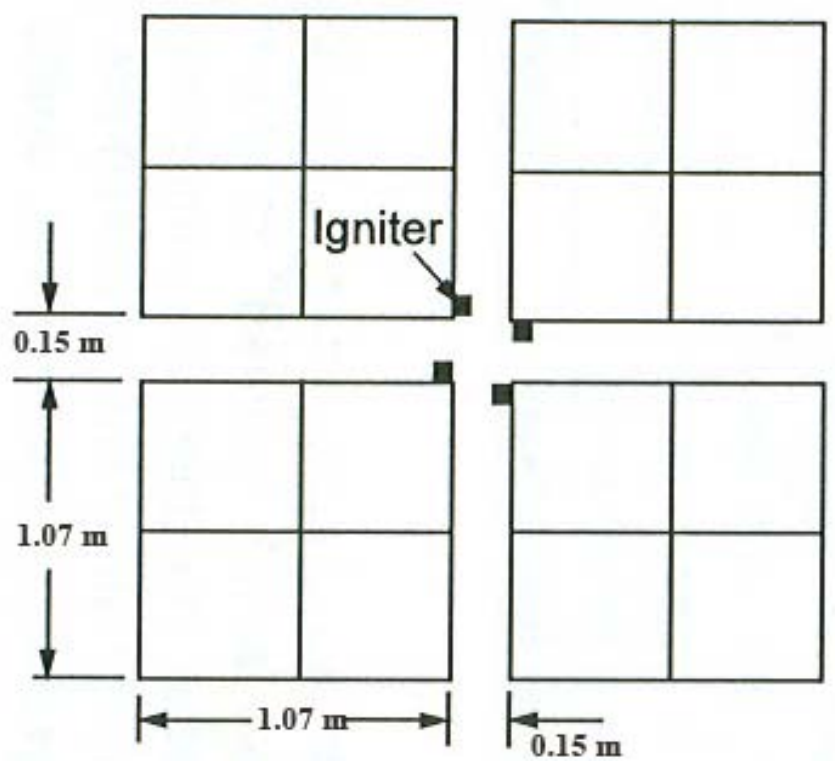

Fig. 2. Plan view of fuel array. 


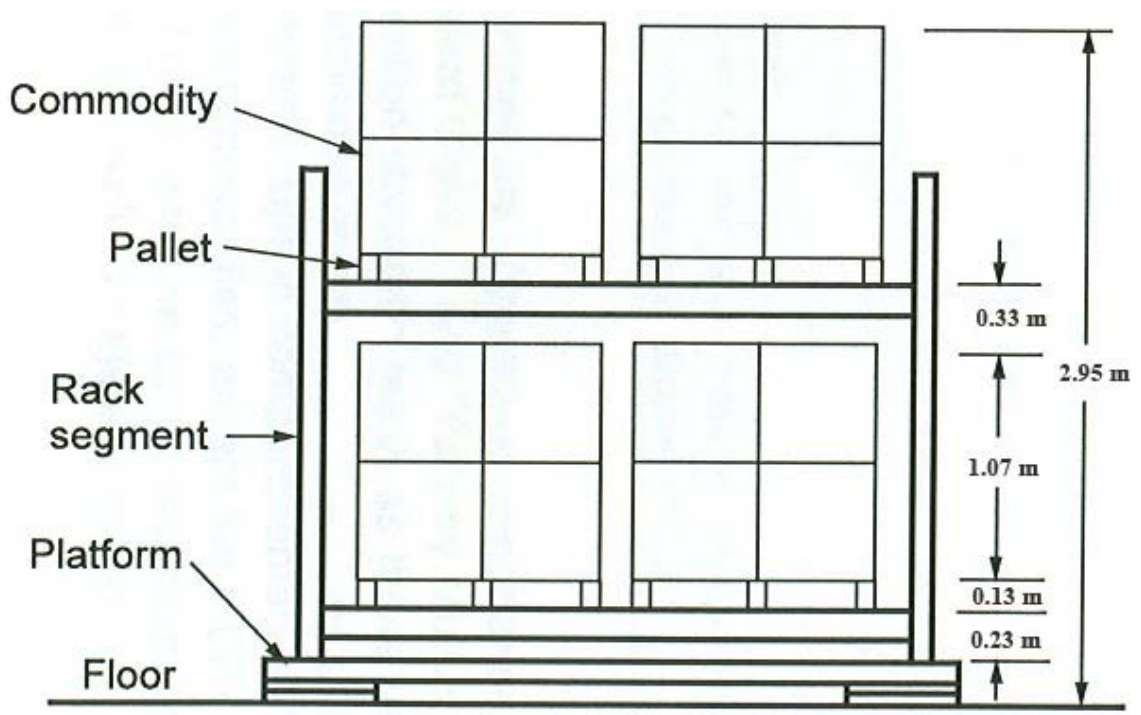

Fig. 3. Elevation view of fuel array.

To apply the method one subjects a given commodity to two or three fire suppression tests and measures the convective and total heat release rates from which one infers the classification. This initial development of the commodity classification from the heat release rate measurement has served the FM Global customers well for many years. Arvidson et al [5] at SP recently developed a similar Commodity Classification method derived from the Chicarello and Troup method. A more physics-based, less empirical methodology would be desirable and more useful for engineering analysis.

It is well known that flame heat flux is closely linked to flame spread and heat release rates. de Ris [6] pointed out that radiation is the dominant mode of heat transfer to burning surfaces at scales greater than 0.2-0.3 meters. He also established that flame sootiness is the primary parameter controlling heat release rates per unit exposed fuel area. A recent study on flame heat flux on commodities in warehouse storage geometry showed that for the same overall heat release rates the peak flame heat flux from propylene $\left(\mathrm{C}_{3} \mathrm{H}_{6}\right)$ flames were 2.8 times greater than those from carbon monoxide (CO) flames [7]. The flame heat flux in storage geometries is a function of heat release rate, fuel sootiness and aisle separation between commodities. The empirical classification method of Chicarello and Troup used overall measurements (heat release rates) from fires having fixed geometry and also required three sprinklered tests. The current study incorporates flame heat flux (measured inside the flame) into the methodology by performing a single free-burn test instead of three sprinklered tests. By incorporating the flame heat flux (a primary driving force in flame spread) into the commodity classification methodology, one should be able to extend the commodity classification of Chicarello and Troup to other geometries and protection options.

Several recent studies have predicted that the flame heat fluxes associated with various commodities are expected to be significantly different. In 1993, Yu et al [8] conducted a series of Required Deliver Density (RDD) [9] tests for the FM Class II and Standard Plastic commodities in rack storage configurations. Yu inferred the effective net heat flux from the fire to the fuel surface for Class II and Standard Plastic commodities to differ by 
more than a factor of two. Such differences in flame heat transfer, if proven, would be vital for ranking the commodities.

\section{ORIGINAL HEAT FLUX PIPE - SINGLE CHANNEL DESIGN}

Traditional instrumentation available for measuring the flame heat flux in full-scale fire tests requires complex, time-consuming installation, and is not sufficiently robust to withstand repeated use in the severe fire environments. Alpert et al [10] developed a novel instrument, the Heat Flux Pipe $\left(\mathrm{HFP}_{1}\right)$ capable of measuring the instantaneous flame heat flux in severe fire environments (Fig. 4). The instrument consists of an outer steel tube and an inner machined aluminum core having a single spiral channel. This channel was shared by the seven (7) thermocouples and the flowing water. The design makes use of the change in water temperature with distance along a water channel within the pipe.
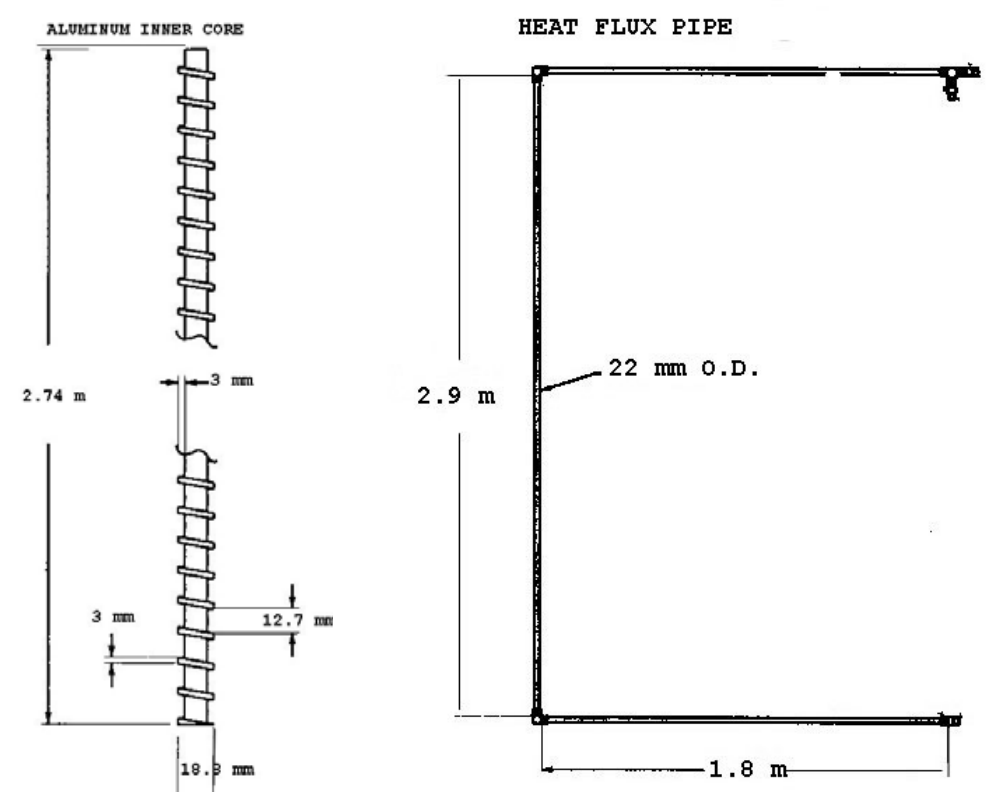

Fig. 4. The Heat Flux Pipe instrument (enlarge aluminum core at left).

As shown in Fig. 4, this $H_{F P}$ (22 mm O.D.) is on the right while the enlarged inner aluminum core (18.8 $\mathrm{mm}$ O.D.) is on the left. There are seven thermocouple junctions, located at $0.15,0.46,0.76,1.07,1.68,2.13$, and $2.74 \mathrm{~m}$ from the bottom of the pipe. This allows for measurement of average heat flux at six locations, $0.30,0.61,0.91,1.37,1.91$, and $2.44 \mathrm{~m}$. During a test, the water flow rate through the Heat Flux Pipe is continuously adjusted to control the water outlet temperature which is held less than $80^{\circ} \mathrm{C}$ to avoid boiling. This single channel $H F P_{1}$ was first calibrated in a Parallel Panel Apparatus [11] and the heat flux measurements agreed with those from Medtherm gauges. However, the water flow rate was peaked at about $0.005 \mathrm{~m}^{3} / \mathrm{min}$ as water pressure was increased to $758 \mathrm{kPa}$. This limitation in water flow rate restricted the heat flux measurement to be significantly below $200 \mathrm{~kW} / \mathrm{m}^{2}$. 


\section{EXPLORATORY TESTS - WITH SPRINKLERS AND ORIGINAL PIPE}

This first test series had to be sprinklered tests. The tests were conducted under the FM Global 5-MW capacity Fire Products Collector [3]. The heat release rate from a free-burn test with Standard Plastic commodity would clearly have exceeded the capacity of the 5-MW Fire Products Collector. In addition, the flame heat flux is expected, based on previous sprinklered test results to be larger than $200 \mathrm{~kW} / \mathrm{m}^{2}$, which is beyond the capacity of $\mathrm{HFP}_{1}$. Sprinklered tests also allow for comparison to previous RDD tests analyzed by Yu. Here tests were conducted for Class II and Standard Plastic commodities. The test procedure was identical to that described by Chicarello and Troup. For the exploratory tests, the hypothetical protection system consisted of quick response (Response Time Index, RTI $=50 \mathrm{ft}^{1 / 2} \mathrm{~s}^{1 / 2}$ ) sprinklers with a temperature rating of $165^{\circ} \mathrm{F}$. The sprinkler pacing was $10 \mathrm{ft}$ x $10 \mathrm{ft}$ and the simulated ceiling clearance was $10 \mathrm{ft}$ above the commodity. The fuel array was ignited with four standard FMRC half igniters (76 mm dia. X $76 \mathrm{~mm}$ long cellucotton, each soaked in $118 \mathrm{ml}$ of gasoline).

The $H F P_{1}$ was placed vertically at the centerline of the $2 \times 2 \times 2$ commodity array. For the Class II commodity test, the water delivered density was set at $0.21 \mathrm{gpm} / \mathrm{ft}^{2}$. This was selected to represent early suppression mode. The nozzles were activated at $t_{a c t}=90 \mathrm{~s}$ and the test lasted about $280 \mathrm{~s}$ (See Fig. 5). After the nozzle activation, the heat release rate continued to rise for about $20 \mathrm{~s}$ before suppression because it took time for water to reach the burning surfaces. This delay-time depends on the fire size, water delivered density and geometry of the burning surfaces.

For the Standard Plastic commodity, test was then conducted with a water delivery density of $0.31 \mathrm{gpm} / \mathrm{ft}^{2}$ (suppression mode). The heat release rate history is also given in Fig. 5. For the Standard Plastic commodity, the simulated sprinklers operated 46 seconds into the fire.

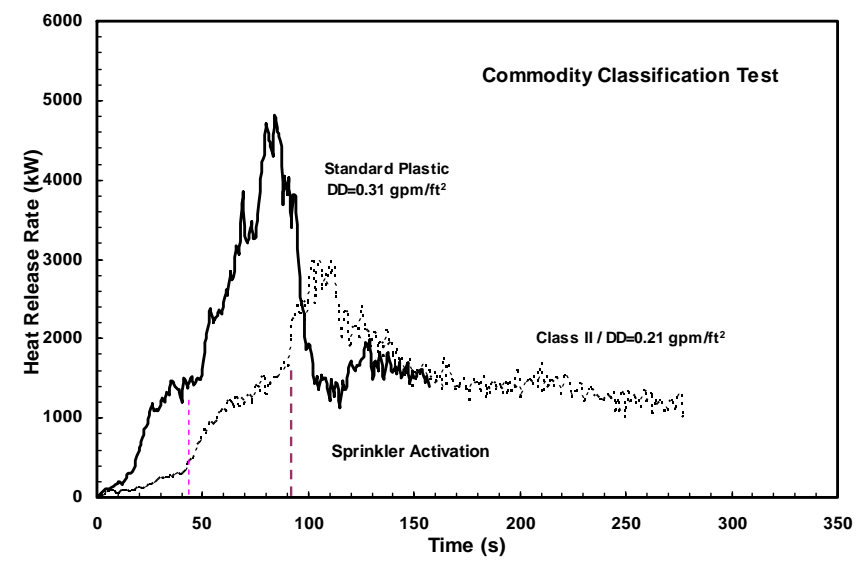

Fig. 5. Heat release rates for Standard Plastic and Class II commodities (sprinklered tests).

For the sprinklered test with Standard Plastic, heat flux values are given in Fig.6. The water temperatures were measured at 6 locations in the pipe and the corresponding average flame heat fluxes were inferred for 5 pipe segments (Fig. 6). At sprinkler activation, the flame heat flux at locations between heights of $0.6 \mathrm{~m}$ to $1.4 \mathrm{~m}$ was about 
$80 \mathrm{~kW} / \mathrm{m}^{2}$ and increased quickly to $192 \mathrm{~kW} / \mathrm{m}^{2}$ before the fire was suppressed. The maximum flame heat flux occurs at $95 \mathrm{~s}$ about $10 \mathrm{~s}$ after the peak heat release rate.

The maximum flame heat flux and the flame heat flux at sprinkler activation are plotted as a function of height (Fig. 7). Comparing the maximum flame heat flux between Class II and Standard Plastic commodities, one can clearly observe the distinct difference in the region of $0.9 \mathrm{~m}$ to $1.4 \mathrm{~m}$ high along the array centerline (114 vs $\left.192 \mathrm{~kW} / \mathrm{m}^{2}\right)$. This factor of about 2 is not inconsistent with Yu's estimate.

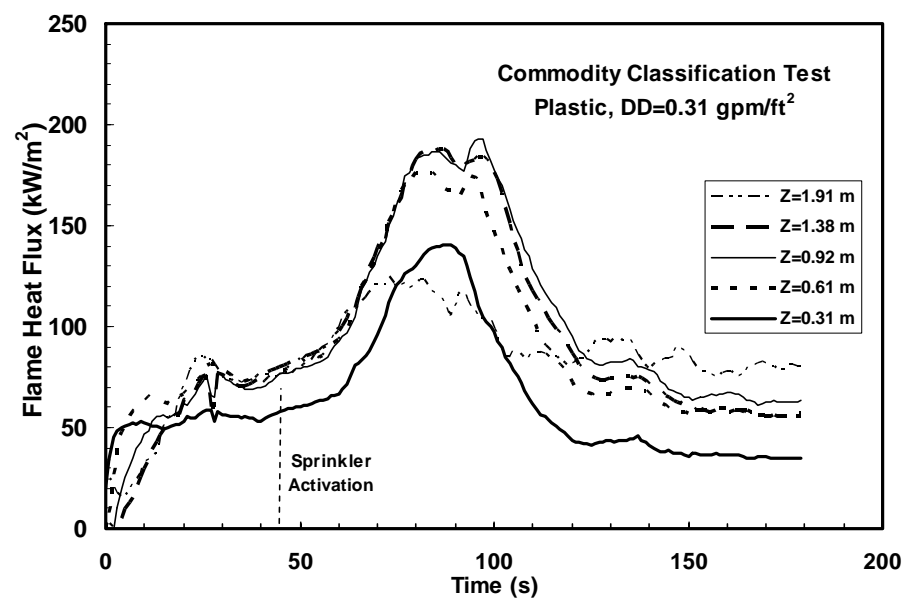

Fig. 6. Flame heat flux histories at various heights along the centerline (standard plastic).

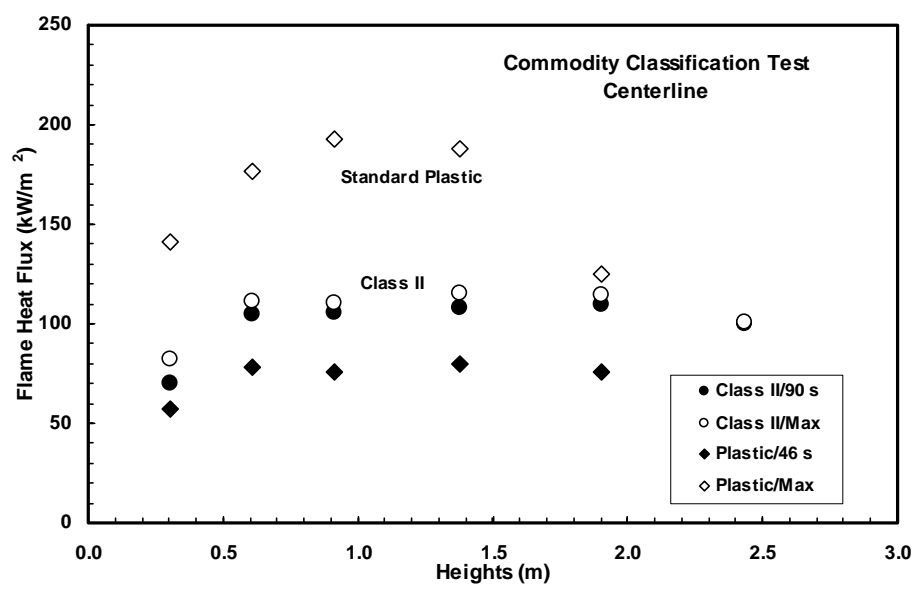

Fig. 7. Flame heat flux distributions at sprinkler activation and at maximum.

\section{NEW HEAT FLUX PIPE - DOUBLE CHANNEL DESIGN}

The measurement of higher heat fluxes requires greater water flow rate. This is achieved by employing two spiral channels, one for the thermocouples and one for the flowing water (Fig. 8). The new Heat Flux Pipe $\left(\mathrm{HFP}_{2}\right)$ is stainless steel tube (19.1 mm O.D. and 
$15.7 \mathrm{~mm}$ I.D.) over aluminum core (15.5 mm O.D.). This pipe is $2.7 \mathrm{~m}$ long. The water channel is $1.6 \mathrm{~cm} \times 0.3 \mathrm{~cm}(5 / 8 \mathrm{in} \times 1 / 8$ in) while the thermocouple channel is $0.2 \mathrm{~cm} \mathrm{x}$ $0.3 \mathrm{~cm}$ (3/32 in x 1/8 in). The Conax 4-mil Inconnel thermocouples (Model K-INC4-UT3) with seal (Model SPG100-040-A5-V) were used. There are nine thermocouples with even spacing of $0.3 \mathrm{~m}$ (12 in). The thermocouple channel was sealed with Omega high temperature cement. The designed water pressure drop through the pipe is about $345 \mathrm{kPa}$ (50 psi) at $0.01 \mathrm{~m}^{3} / \mathrm{min}(10 \mathrm{LPM})$. The flow rate can be easily increased to $0.015 \mathrm{~m}^{3} / \mathrm{min}$ (15 LPM) for larger heat fluxes.

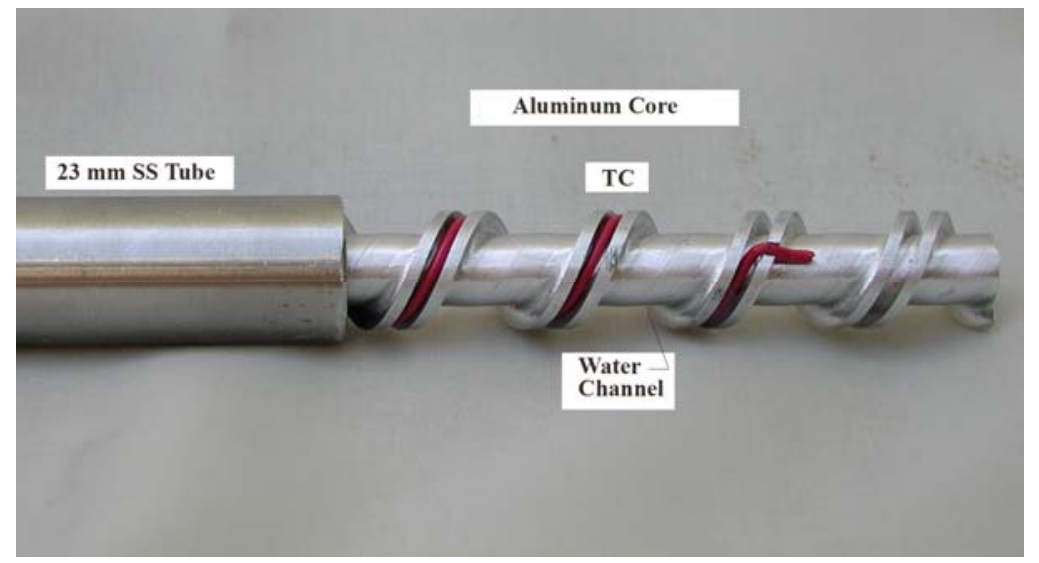

Fig. 8. Two-Channel Heat Flux Pipe.

The characteristic (i.e., 1-e folding) time constants for heating and cooling were calibrated using a custom built electrical oven having a cavity of $0.15 \mathrm{~m}$ (6 in) long $\mathrm{x}$ $0.10 \mathrm{~m}$ (4 in) diameter and a power output of $1 \mathrm{~kW}$. The characteristic times for instantaneously applying and removing a constant heat flux were 6.4 seconds and 4.7 seconds respectively. These time constants are consistent with the original design estimate of about 5.8 seconds, assuming that the pipe is solid aluminum and suddenly heated by a constant heat flux of $100 \mathrm{~kW} / \mathrm{m}^{2}$.

\section{FREE-BURN TESTS - WITH NEW PIPE}

In 2003, FM Global built a new fire testing facility with a 25 MW Fire Products Collector that could accommodate free-burn fire tests for $2 \times 2 \times 2$ commodity array. Three commodities (Class II, wood pallets and FM Standard Plastic) were used in the present free-burn test series. The $\mathrm{HFP}_{2}$ was again placed at the centerline of the commodity array.

The results of free-burn tests are presented in Figs. 9-12. For Class II commodity, the water temperature histories at 9 locations in the pipe were measured (Fig. 9) and hence the corresponding average flame heat fluxes at 8 locations were plotted in Fig. 10. The heat release rate histories are given in Fig. 11. For the Class II commodity, the flame heat flux histories showed large differences with height above the platform shown in Fig. 3 and had a maximum of $150 \mathrm{~kW} / \mathrm{m}^{2}$ (Fig. 10). The peak heat release rate was approximately constant at $10 \mathrm{MW}$ between 2.5 to $8 \mathrm{~min}$ (Fig. 11). For easy comparison, a representative maximum heat flux distribution is plotted in Fig. 12. 


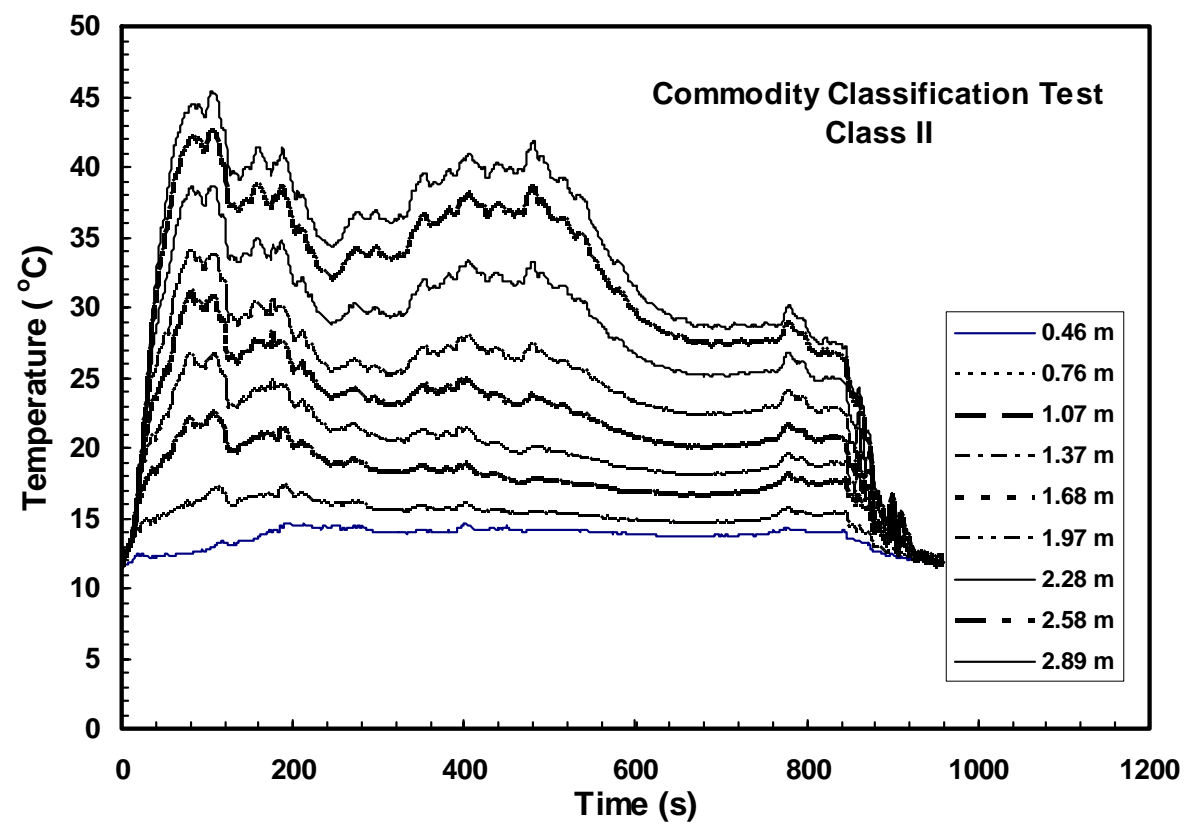

Fig. 9. Temperature distributions at various locations on HFP (Class II commodity).

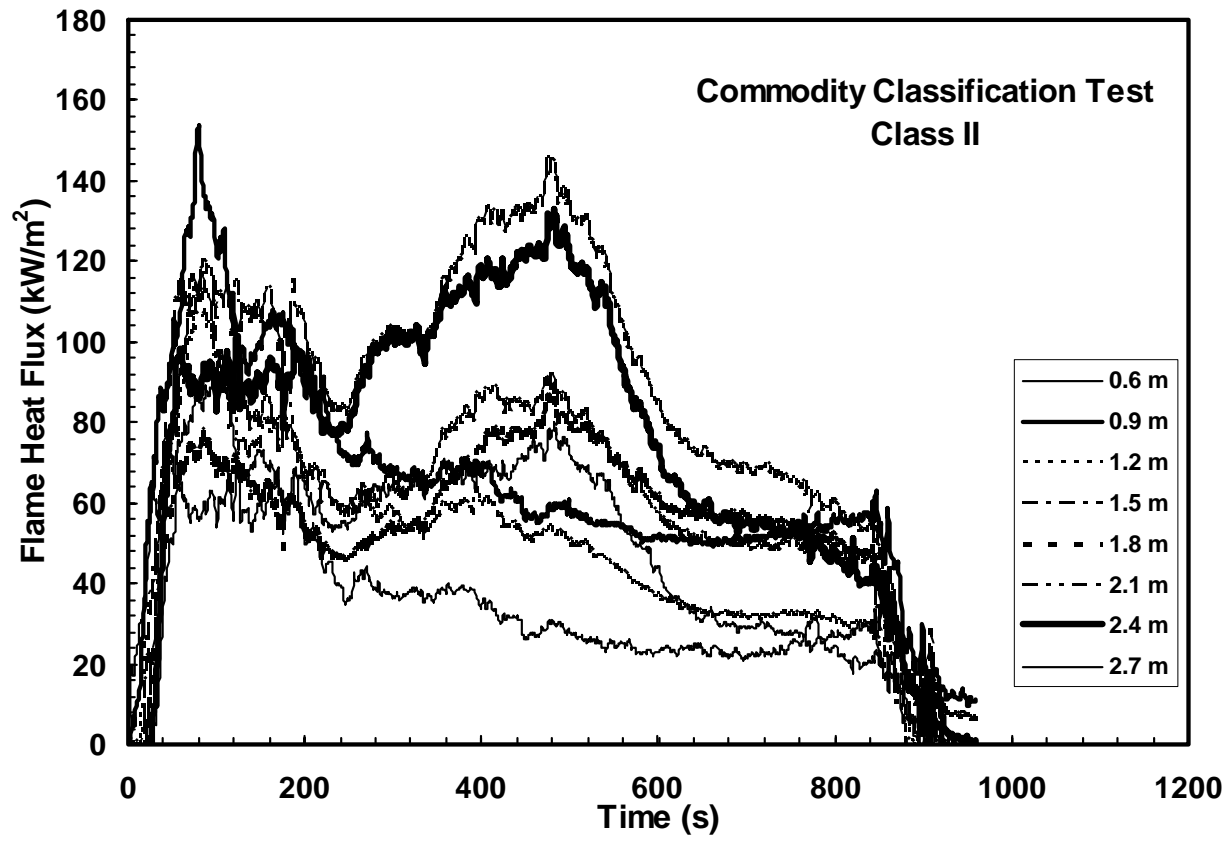

Fig. 10. Average flame heat flux distribution along HFP (Class II commodity). 


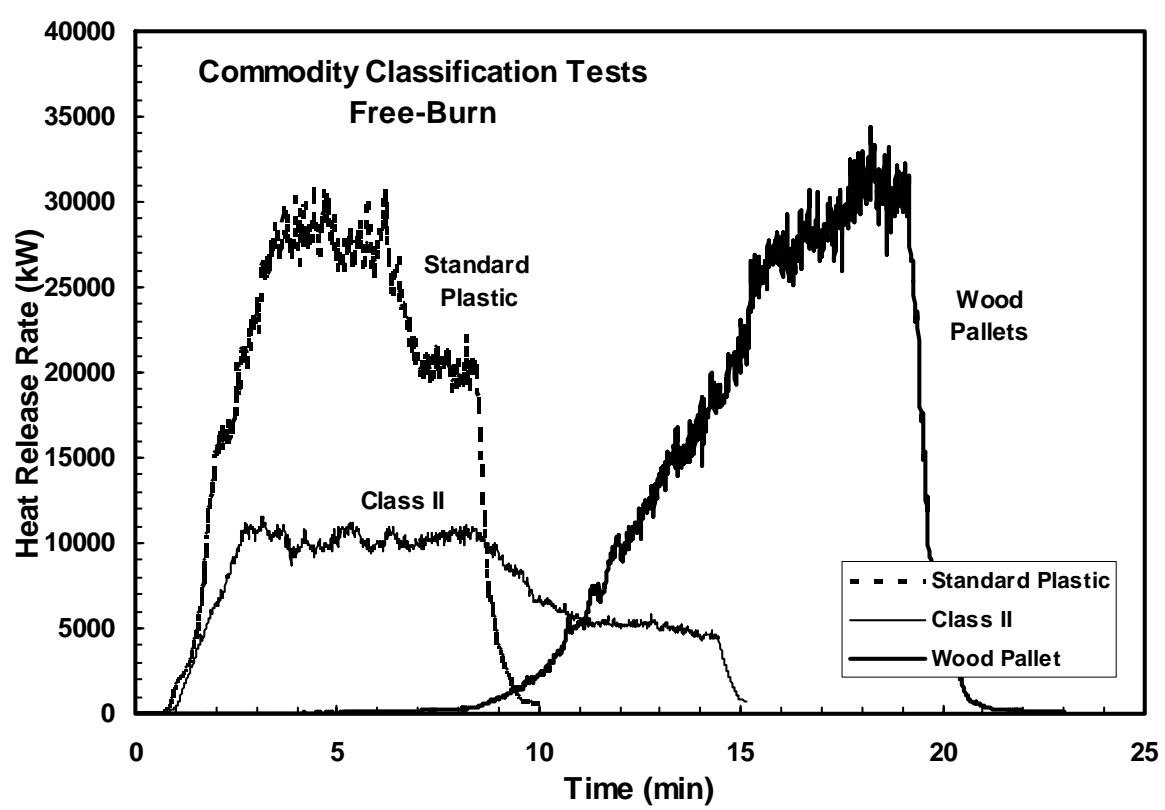

Fig. 11. Heat release rate distributions for various commodities.

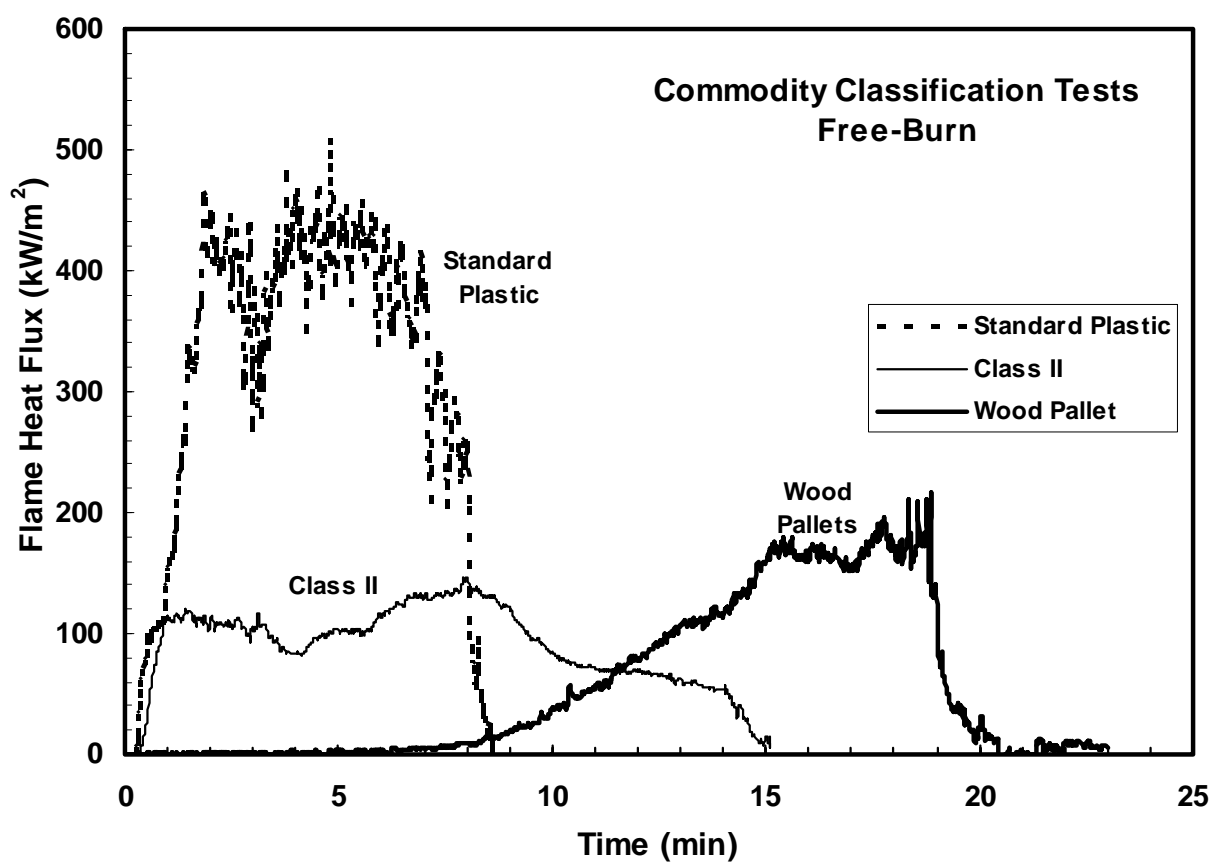

Fig. 12. Maximum heat flux distributions for various commodities.

For wood pallet commodity, the fuel array consisted of eight, nominal $1.2 \mathrm{~m}(4 \mathrm{ft})$ high, stacks of ordinary wood pallets supported by a double-row rack segment in a two wide by two deep by two high configuration (standard 2x2x2 array). Each stack was comprised of 
nine, nominal $1.07 \mathrm{~m} \mathrm{x} 1.07 \mathrm{~m}$ x $0.13 \mathrm{~m}$ high (42 in x 42 in x 5 in high), slatted, two-way, hardwood pallets. The burning of wood is a much more complex process than that of corrugated cardboard or synthetic polymers [12]. To ensure the proper ignition of the wood pallets, a larger ignition source (i.e., four full igniters, $76 \mathrm{~mm}$ dia x $152 \mathrm{~mm}$ long cellucotton each soaked in $236 \mathrm{ml}$ of gasoline) was used. The fire took about ten minutes to develop and the heat release rate reached about $32 \mathrm{MW}$ (Fig. 11). The maximum heat flux for wood pallet commodity was at $190 \mathrm{~kW} / \mathrm{m}^{2}$ because the effective mean free path is shorter than that for the Class II commodity.

For the FM Standard Plastic commodity, the test lasted about nine minutes and the heat release rate reached $29 \mathrm{MW}$. The water flow rate was increased to $0.012 \mathrm{~m}^{3} / \mathrm{min}$ (12 LPM) and the water temperature was kept below $80^{\circ} \mathrm{C}$. The maximum heat flux was at about $440 \mathrm{~kW} / \mathrm{m}^{2}$, the largest heat flux measured so far by this device. This heat flux might seem large - it corresponds to the heat flux from a black body at $1667^{\circ} \mathrm{K}$. It is the first time heat fluxes have been measured inside a large polystyrene fire. One must recall that the measurement is made by a $19 \mathrm{~mm}$ cold pipe that imposes negligible local cooling and blockage of incoming radiation. Heat flux to large cold surfaces would be considerably lower.

The free-burn test results are summarized in Table 1 . The values of critical heat flux (CHF), defined as the heat flux below which ignition will not occur, and chemical heat of combustion $\left(\Delta \mathrm{H}_{\mathrm{c}}\right)$ are taken from the SFPE Handbook [13]. As shown in Table 1, Class II commodity clearly has the lowest hazard level among the three tested commodities. Between the wood pallet and Standard Plastic commodities, the heat release rates are comparable and the centerline maximum flame heat fluxes are $190 \mathrm{~kW} / \mathrm{m}^{2}$ and 440 $\mathrm{kW} / \mathrm{m}^{2}$ respectively. The burning surface areas for Class II and Standard Plastic are comparable while the burning surface area for wood pallet is much larger than either Class II or Standard Plastic. This may explain the largest maximum mass loss rate for wood pallets.

Table 1. Summary of the free-burn test results.

\begin{tabular}{|l|c|c|c|}
\hline & Class II & Wood Pallet & Standard Plastic \\
\hline Initial Mass (kg) & 305 (corr. paper) & 1349 & $\begin{array}{c}160 \text { (corr. paper) } \\
250 \text { (polystyrene) }\end{array}$ \\
\hline $\begin{array}{l}\text { Maximum Mass Loss } \\
\text { Rate (kg/min) }\end{array}$ & 38.8 & 112.7 & 73.4 \\
\hline $\begin{array}{l}\text { Heat Release Rate } \\
(\mathrm{kW})\end{array}$ & 11,000 & 32,000 & 29,000 \\
\hline $\begin{array}{l}\text { Flame Heat Flux } \\
(\mathrm{kW} / \mathrm{m} 2)\end{array}$ & 140 & 190 & 440 \\
\hline $\begin{array}{l}\text { Heat of Combustion } \\
\Delta \text { Hc (kJ/g) }\end{array}$ & $\begin{array}{c}13.2 \text { (corrugated } \\
\text { paper) }\end{array}$ & 17.1 (oak) & $\begin{array}{c}39.2 \text { (polystyrene) } \\
13.2 \text { (corrugated } \\
\text { paper) }\end{array}$ \\
\hline $\begin{array}{l}\text { Critical Heat Flux, } \\
\text { CHF (kW/m2) }\end{array}$ & 10 & 10 & 13 \\
\hline
\end{tabular}

\section{SUMMARY}

A new tool, the Heat Flux Pipe, has been demonstrated to be a robust instrument to measure flame heat flux in large-scale fire tests. It was successfully used in fires of up to $30 \mathrm{MW}$ and withstood flame heat flux of $440 \mathrm{~kW} / \mathrm{m}^{2}$. The Heat Flux Pipe can be a useful 
instrument for other large-scale fires. For the present unsuppressed test series, large maximum centerline flame heat fluxes were measured for Class II, wood pallet, and Standard Plastic commodities, i.e., $140 \mathrm{~kW} / \mathrm{m}^{2}$ (Class II), $190 \mathrm{~kW} / \mathrm{m}^{2}$ (Wood Pallet), and $440 \mathrm{~kW} / \mathrm{m}^{2}$ (Standard Plastic). These are the relative fire hazards when the suppression system fails. For the exploratory tests (i.e., RTI=27.6 $\mathrm{m}^{1 / 2} \mathrm{~s}^{1 / 2}$ and temperature rating $=286^{\circ} \mathrm{F}$ ), the maximum flame heat fluxes were $114 \mathrm{~kW} / \mathrm{m}^{2}$ and $192 \mathrm{~kW} / \mathrm{m}^{2}$ for Class II and Standard Plastic respectively. However, there are many different sprinkler protection systems available today (i.e., different RTI's and temperature ratings). For any hypothetical sprinkler protection system, Yu's sprinkler onset model [4] provides the time of onset and the unsuppressed test results give the corresponding flame heat flux. But the flame heat flux at sprinkler onset is related to the required water delivered density for suppression [8]. Hence, one can obtain an optimum suppression system for a commodity with one free burn test. Clearly, flame heat flux is a vital component of flame spread and the difference in flame heat flux between commodities can be exploited to better quantify the commodity hazards. Efforts are continuing to obtain flame heat flux data for more commodities so that a more effective methodology can be developed to rank commodity hazards and the corresponding protection requirement.

\section{ACKNOWLEDGEMENTS}

The author would like to express his gratitude to Mr. Jeffrey Chaffee, Mr. Michael Skidmore, Mr. Jason Tucker and other staff at the FM Global Research Campus for carrying out the fire tests. He also thanks Dr. John L. de Ris and Dr. Robert G. Bill, Jr. for their involvement and technical discussions. This study was supported by FM Global.

\section{REFERENCES}

[1] Chicarello, P.J. and Troup, J.M., "Fire Products Collector Test Procedure for Determining the Commodity Classification of Ordinary Combustible Products," Technical Report, FMRC J.I. 0R0E5.RR, Factory Mutual Research, Norwood, MA, August, 1990.

[2] Data Sheet 8-1, Commodity Classification, FM Global Operating Standards $\odot$, Factory Mutual Insurance Company, Revised, May, 2001.

[3] Heskestad, G., “A Fire Products Collector for Calorimetry into the MW Range,” FMRC J.I. 0C2E1.RA, Factory Mutual Research Corporation, June, 1981.

[4] Kung, H.C., Spaulding, R.D. and Yu, H.Z., "Response of Sprinkler Links to Rack Storage Fires,” Technical Report, J.I. 0G2E7.RA (2), Factory Mutual Research Corporation, Norwood, MA, November, 1984.

[5] Arvidson, M. and Lonnrmark, A., "Commodity Classification Tests of Selected Ordinary Combustible Products,” SP Report 2002:03, Boras, Sweden, 2002.

[6] de Ris, J., "Fire Radiation - A Review," $17^{\text {th }}$ Symposium (International) on Combustion, The Combustion Institute, Pittsburgh, PA, p.1003, 1979.

[7] Ingason, H. and de Ris, J., "Flame Heat Transfer in Storage Geometries," Fire Safety Journal, 31, pp.39-60, 1998.

[8] Yu, H.Z., "Heat Absorption by Water in Rack-Storaged Corrugated Cardboard Carton Fires," The Proceedings of the Fifth International Symposium of Fire 
Safety Sciences, International Association for Fire Safety Science, pp. 923-933, 1996.

[9] Yu, H.Z., Lee, J.L., and Kung, H.C., "Suppression of Rack-Storage Fires by Water," In Fire Safety Science-Proceedings of the Fourth International Symposium, International Association for Fire Safety Science, pp.901-912, 1994.

[10] Alpert, R.L., de Ris, J.L., and Orloff, L., "Heat Flux Measurement Pipe and Method for Determining Sprinkler Water Delivery Requirement," U.S. Patent No. 6,499,357 B2, December 31, 2002.

[11] Wu, P.K., "Parallel Panel Fire Tests for Flammability Assessment,” Proceeding of the $8^{\text {th }}$ International Fire Science \& Engineering Conference, Edinburgh, Scotland, June 29-July 1, pp. 605-614, 1999.

[12] Drysdale, D., An Introduction to Fire Dynamics, Second Edition, John Wiley \& Sons, Inc., New York, NY, p.182, 2000.

[13] Tewarson, A., "Generation of Heat and Chemical Compounds in Fires," The SFPE Handbook of Fire Protection Engineering ( $\left.{ }^{\text {nd }} e d\right)$, Chapter 3, Section 4, National Fire Protection Association, Quincy, MA, 2001. 